\title{
PREVENTION OF COMPUTER WORKER HEALTH DISTURBANCES CAUSED BY PHYSICAL AND PHYSIOLOGICAL RISK
}

\author{
Viive Pille ${ }^{1}$, Kristel Oha $^{2}$, Mariliis Lauri ${ }^{1}$, Piia Tint ${ }^{1 \#}$, Varje-Riin Tuulik ${ }^{1}$, Viiu Tuulik ${ }^{1}$, \\ and Kalju Meigas ${ }^{1}$ \\ ${ }^{1}$ Tallinn University of Technology, Ehitajate 5, 19086 Tallinn, ESTONIA \\ 2 Tartu University, Ülikooli 18, 50090 Tartu, ESTONIA \\ \# Corresponding author, piia.tint@ttu.ee
}

Communicated by Modra Murovska

\begin{abstract}
This investigation was carried out in the frames of the Interreg $4 A$ project "Workability and Social Inclusion" headed by the Arcada University of Applied Life. Tallinn University of Technology and Riga Stradinš University were involved in the project. A questionnaire based on the Nordic, WAI (Work Ability Index), and Kiva questionnaires was compiled to study psychosocial and physical working conditions at computer-equipped workplaces for 192 workers. The results showed that the computer workers assess their health status considerably high. They are optimistic in solving the problem that the monotonous work with computers will continue and believe that their health status in the future will stay at the same level using the steadily enhancing rehabilitation means. The most injured regions of the body were the right wrist and the neck. The novelty of the study consists in the graphical co-analysis of different groups of questions presented to the workers, which allows to assess the physiological and psychological factors in complex. The rehabilitation means have to be developed and the possibility for rehabilitation must be made available to the greatest possible number of workers. The workers were divided into two groups: Group $A$, the length of employment with computers under 10 years (included) and Group B, having been working with computers over 10 years. These groups were found to differ in the perception of psychosocial risk factors at the workplace. Group $B$ assessments for psychosocial working conditions were better than those of group $A$. In group B, employees appeared to be more afraid of losing their jobs and therefore they were not so demanding for the work atmosphere as in group $A$.

Key words: computer workers, musculoskeletal disorders, occupational stress.
\end{abstract}

\section{INTRODUCTION}

The majority $(90 \%)$ of registered occupational diseases in Estonia in 2012 were associated with musculoskeletal disorders (MSDs) (Anonymous, 2012). Musculoskeletal disorders cause pain in the neck, shoulders, elbows, back, and wrist. Intensive use of computers causes other major health problems like tissue damage, imbalance in blood flow, and development of the carpal tunnel syndrome (Oha et al., 2010). Computer-workers are under pressure as increasing amounts of work have to be done within a limited time. Stress is not only a feeling. It changes functions in the body: release of a variety of hormones, increased breathing, quickened pulse, and the production of more stomach acid. Computer work causes social problems: it distracts an individual from normal social or family relations and this in turn may lead to the depression (Eltayeb et al., 2007). The physical complaints of computer workers are very closely connected with psychological disturbances (Zak- erian and Subramanian, 2009). The first symptoms of stress to appear can be physical (lack of appetite, sleeplessness, headache, pain in chest) and psychological (difficulty in concentrating, imbalance, anxiety, irritability, difficulty in making decisions, burnout). Stressors like time limits, bad relationships between co-workers or with the employer, and too much work wanted by the employer are considered to be factors that can cause fatigue in upper extremities (Feuerstein et al., 2004; Kulin and Reaston, 2011; Panari et al., 2012).

Illnesses and social problems develop under permanent stress. The interaction between the human body and the work environment is complex and four important systems (central nervous, automatic nervous, endocrine, and immune) of the person are involved in this network (Raja et al., 1996). Job stress to computer workers can cause frustration, depression, stomach problems, muscle and psychological tension (Malinska and Bugajska, 2010). 
Working with computers presents ergonomic risks due to the static postures that are maintained for a long time; they are repetitive and sometimes forceful (Nag et al., 2009; Zakerian and Subramanian, 2009; Brauer et al., 2010; Mueller and Hassenzahl, 2010; Šmite and Ancane, 2010). The overuse syndrome caused by physical overload includes common lesions such as channel bursitis, mono-and polyneuropathies, and compression (Orsila et al., 2011). The most important work activities (typing, writing, using a computer mouse) by computer-workers can cause repetitive strain injuries to the workers by affecting the upper and lower extremities.

The understanding of worker stress in the workplace is attracting growing interest in occupational health psychology. Increased levels of stress compromise the immune system, reduce cardiovascular functioning, affect blood pressure and hormone excretion and increase the risk of accidents. Psychological risk factors have been defined as aspects related to the planning, organisation, and management of the job, social contexts, and physical, social and psychological damage (Panari et al., 2012).

The emotional side of a person and the physical side are closely connected (Šmite and Ancane, 2010); low back pain as a musculoskeletal disorder (MSD) is associated with the physical and emotional factors.

Every worker has to be provided with the possibility to control his/her own preferred microenvironment. Inability to control one's working conditions aggravates string emotions and possible interpersonal conflict situations. Productivity is reduced under poor working conditions (Tanabe, 2004).

Rehabilitation from stress and musculoskeletal disorders is also important. Workers with lower health, lower workrelated well-being or lower work ability are at risk for ending up in unstable temporary employment or unemployment (Wagenaar et al., 2012).

Supplementary breaks and exercises are needed for office workers to prevent musculoskeletal disorders (Galinsky et al., 2007).

The aim of the investigation was to increase the workability, stress management, good leadership behaviour and thereby social inclusion of the workforce. We conducted: 1) a qualitative study (questionnaires for determination of health disturbances of computer workers, to ascertain the workers opinion of their job psychological and physiological sides and stress assessment; connections between the psychological and physiological risk factors) and 2) a quantitative study (measurement of fatigue of muscles).

\section{MATERIALS AND METHODS}

The work was carried out in the frames of the Interreg 4A project "Workability and Social Inclusion" headed by the Arcada University of Applied Life of Finland. Tallinn Uni- versity of Technology and Rīga Stradiņš University were also involved in the project. Permission for the research was granted by the Medical Ethics Committee.

Questionnaires. A questionnaire based on the Nordic (Lindström et al., 2000), Work Ability Index (WAI) (Tuomi et al., 1998), and Kiva (Näsman, 2011) questionnaires was compiled and forwarded to the workers by Internet or as a hard copy.

The Nordic questionnaire assesses the health risks and health disturbances at work.

The Work Ability Index is based on answers to a series of questions that take into consideration the demands of workers to the job and fulfilment of them during the work. The interview was carried out by an occupational health professional who rated the responses according to the instructions.

The Kiva questionnaire characterises the wellbeing of workers at work. The ratings are given in an 8-point scale (1 not at all, 8 - very much so, certain or well). The Kiva questionnaire is composed of seven questions:

1. Have you enjoyed coming to work in the last weeks?

2. I regard my job meaningful.

3. I feel in control of my work.

4. I get on with my fellow-workers.

5. My immediate superior performs as superior.

6. How certain are you that you will keep the job with this employer?

7. How much can you influence factors concerning your job?

192 workers from different office-rooms from different institutions (including high school, hospitals, enterprises, service institutions etc.) were interviewed about the health risks and health disturbances connected with their work. The health disturbances were specified.

Determination of fatigue in muscles. A myometer "MYOTON-3" was used to diagnose the functional state of skeletal muscles of office workers. The myometer is a hand held state device developed at University of Tartu, Estonia (Vain and Kums, 2002). The Myoton exerts a local impact on biological tissue by means of a brief mechanical impulse. The impact force is small enough so that it causes no changes in the neurological reaction of the biological tissue. The tissue responds to the mechanical impact with damping or oscillation, which is registered by an acceleration sensor located on the measuring tip of the device (Fig. 1).

For statistical data processing, the software SPSS.13 (Windows) was used. The arithmetic mean and standard deviation (SD) were calculated. To ascertain connections between the characteristics, the Spearman rank correlation ( $\mathrm{r}-$ correlation coefficient) was applied, differences between the 

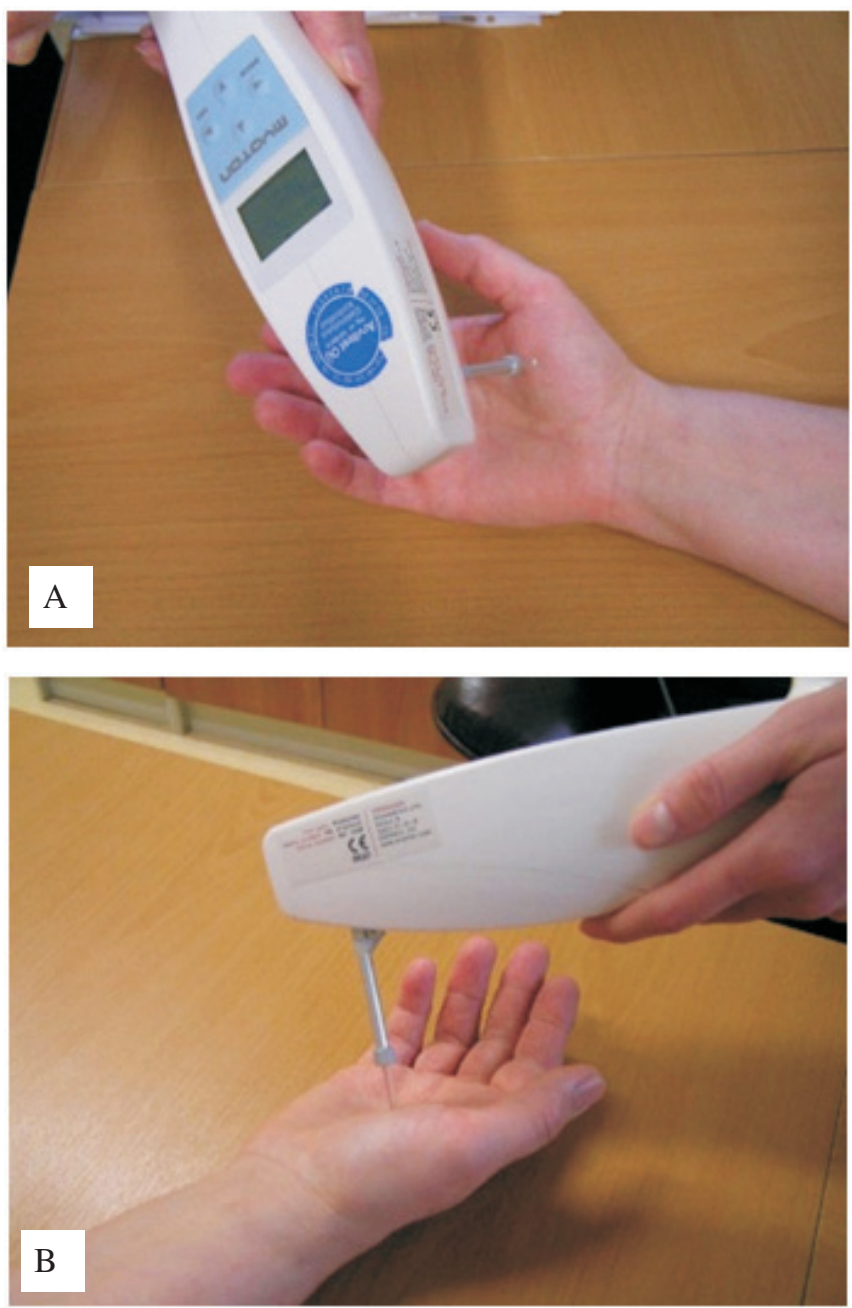

Fig. 1. Myometer (A); measurement of muscles stiffness with the myometer (B).

groups were tested with a Student's t-test. The difference $p<0.05$ was considered statistically significant.

\section{RESULTS}

Summary of the questionnaires. Table 1 presents the results of the survey involving 181 office workers working with personal computers (69 men and 122 women) about their health disturbances. Only correctly filled questionnaires were used (181 from 192 investigated). The average age of male respondents was 40.8 years $(S D=10.0)$ and 45.6 years for female respondents $(S D=9.0)$. People who responded had been working in the same job for 9.5 years. The respondents were divided into two groups: A $(n=125)$ working with a PC up to 10 (inclusive) years and B $(\mathrm{n}=56)$ working with computers over 10 years. The respondents were predominantly with higher education and married (Table 1). According to the Work Ability Index questionnaire, both groups scored an average of 8 points (1-10 point scale) for their current level of performance compared to the best level of life. Both groups rated their performance considering the physical and mental work load as fairly good (4.4).
Table 1

HEALTH COMPLAINTS OF RESPONDENTS STATED IN THE QUESTIONNAIRE (NORDIC, WAI)

\begin{tabular}{lc|c}
\hline \multicolumn{1}{c|}{ Health complaint } & $\begin{array}{c}\text { Group A* }(\mathrm{n}=125) \\
\text { Number of workers } \\
(\%)\end{array}$ & $\begin{array}{c}\text { Group B** }(\mathrm{n}=56) \\
\text { Number of workers } \\
(\%)\end{array}$ \\
\hline Musculoskeletal disorders & $67(53.6)$ & $28(50.0)$ \\
Cardiovascular disturbances & $26(20.0)$ & $25(45.0)$ \\
Visual disturbances & $25(16.0)$ & $13(23.0)$ \\
Overweight & $25(20.0)$ & $14(25.0)$ \\
Health status good & $69(55.0)$ & $24(43.0)$
\end{tabular}

* Length of service with a $\mathrm{PC} \leq 10$ years, $\mathrm{SD}=10.0$; ** length of service with a $\mathrm{PC}>10$ years; $\mathrm{SD}=9.0$

In Group A, musculoskeletal disorders were observed by 67 (53.6\%) people. Among them, 59 diagnoses of MSDs were given by physicians, cardiovascular disturbances were observed by 26 people $(20.8 \%)$ of which 13 were diagnosed by physicians, and visual disturbances were mentioned by $20(16 \%)$ persons (15 of them physician-diagnosed). The problem of being overweight in Group A occurred in 25 (20\%) people; 22 cases of them were diagnosed by the doctor. Diabetes occurred in two people.

In Group B, MSDs were observed by 28 people (50\%), 23 of whom had been diagnosed by a physician; the cardiovascular disorders were observed by $25(45 \%)$ people, 10 of them diagnosed by the physician; and visual disturbances occurred in 13 (23\%) people, 7 cases of which were diagnosed by a medical doctor. The number of overweight persons in Group B was $14(25 \%)$ and all of them also had been given a warning from a medical doctor.

Regarding the impact of the health status on workability, 69 $(55 \%)$ of persons from Group A gave a mark 6 (there were no obstacles for continuing their job); 44 (35\%) of the workers gave 5 points (meaning that they were able to perform the professional tasks, but there were some signs of disease); 6 persons gave 4 points of a top score of 10 (they had to reduce the work pace sometimes) and 1 person gave 3 points as he thought that he had to change the work-pace.

In Group B, the results were as follows: 24 people (43\%) gave 6 points; 23 persons $(41 \%) 5$ points; 6 persons rated themselves at 4 points and 1 person at 3 points. Both groups had a sick leave of a maximum of 9 days during the last 12 months. Based on the current state of health, both groups (93\% of the respondents) believed that they were almost certainly able to continue with their current job after two years. In Group A, 3\% of respondents and in the Group B $7 \%$ were not confident of that.

In rating of mental resources, both groups of respondents (below and above 10 years of service) enjoyed their everyday activities, quite often they had been active and they were optimistic about the future. However, statistics showed that people who have worked under 10 years with PC evaluated their mental resources slightly lower. 
The Kiva questionnaire (scale 1-10) revealed that in Group A, people enjoyed coming to work (assessed by 6.7 points) with 8.2 points considered the importance of the work for them, work process at 8.0 points, relationships with coworkers at 8.5 points and the relationship with the employer at 7.4 points. Confidence of continuing with the same employer was assessed at 7.4 points and 6.8 points were given to the possibility to influence on their work process.

In Group B the respondents assessed the enjoyment of coming to work at 7.3 points, the importance of the work at 8.5 points, and the possibility to control the work process at 8.3 points. Relationships with the co-workers was scored at 8.5 points and with the employer at 7.1 points. The respondents gave 6.8 points to confidence to continue with the same employer and 6.8 points to the possibility to influence their own work process.

Determination of fatigue in muscles. MSDs were examined in depth for 34 display unit workers (Table 2). The Nordic questionnaire was used beforehand to identify persons who might have MSDs with the aim to diagnose the disease in the early stage. The Myoton was used to estimate abductor muscle tone and muscle stiffness. Pain intensity was evaluated on a 10-point scale. The body estimated mean body mass index was $25.0(\mathrm{SD}=5.0)$.

The majority of the respondents declared the existence of two or more local pain points. Neck pain complaints occurred in 22 respondents $(64.7 \%)$, and the severity of pain was assessed at an average of 4.18. Right shoulder pain occurred in 15 patients $(44.0 \%)$ and left shoulder pain in 14 $(41.0 \%)$ of the respondents. Pain in shoulders was assessed with 3.80 (right) and 2.80 (left) points. Wrist pain in the right arm was declared in 7 cases (20.6\% of all) and the left wrist pain only in two cases (4.5\%), with severity of 4.57 (right) and 4.01 (left). Back pain was a complaint of 16 $(47.0 \%)$ persons with severity of 4.28 points (Table 2$)$. The presence of pain was generally of short-term duration, mostly for 1-7 days.

Myometric study revealed differences in the pain severity of complaints from employees with muscle pain and trapeze muscle pain in tonus and muscle stiffness.

Table 2

RESULTS OF THE MEASUREMENT OF FATIGUE IN MUSCLES USING A MYOTON*

\begin{tabular}{lcc}
\hline \multicolumn{1}{c|}{ Pain region } & $\begin{array}{c}\text { Number of workers } \\
(\%) * *\end{array}$ & $\begin{array}{c}\text { Severity of pain } \\
(0-10)\end{array}$ \\
\hline Neck & $22(64.7 \%)$ & 4.18 \\
Shoulder, right & $15(44.0 \%)$ & 3.80 \\
Shoulder, left & $14(41.0 \%)$ & 2.80 \\
Elbow, right & $2(5.9 \%)$ & 4.71 \\
Elbow, left & $2(5.9 \%)$ & 2.12 \\
Wrist, right & $7(20.6 \%)$ & 4.57 \\
Wrist, left & $2(5.9 \%)$ & 4.01 \\
Back & $16(47.0 \%)$ & 4.28
\end{tabular}

$*$ No of respondents $-34: * * \mathrm{SD}=5.0$
As muscle strain is occurs from a static posture, it can be influenced by work psycho-emotional stress.

Thus, it might be concluded that static muscle tension caused increased muscle tone. In front of the monitor, the guiding hand receives the most load. It is important to find the organisational measures that would ensure regular breaks and exercises, possibly combining them.

\section{DISCUSSION}

The differences among groups in the studied factors are shown in Figure 2.

The results of Kiva questionnaire gave good marks (work relations were assessed as good by the respondents): the average rating of seven Kiva questions was 7.6. The employees enjoyed coming to work during the last week; work was important to them; they had the possibility to control their own work process; relationships with colleagues were good; the direct superior acted well; and they considered that they will continue their work with the same employer. Work stress was felt by $1 / 3$ of respondents to "some extent" and by $1 / 3$ "only a little"; "rather much" and "very much" stress was felt only by $10 \%$ of respondents.

Most of the employees considered (Fig. 2A) that they were able to recover after workdays or work shifts. The majority of workers were enthusiastic about their work and felt themselves strong and powerful in the workplace. More than a half of the employees felt that their health, compared to peers, was "good" or "rather good". Overall, the workers were slightly more satisfied with their job than with their current life. At the same time, both satisfaction with their job and satisfaction with their current life was relatively high. Job satisfaction was relatively high (concluded from the Kiva questionnaire), and therefore other questions concerning their welfare gave the same result (Fig. 2B). Predominantly, workers could use their knowledge and skills in the workplace. Generally, the work was not one-sided. Approximately one half of the workers had the periods in their work that were too complicated; and $40 \%$ of workers felt that there were situations that produced negative emotions to them. More than $2 / 3$ of the respondents were in a hurry to get the job done and a similar proportion of workers had to stop some on-going work because of another urgent activity. Generally, the amount of the information given by the employers to the employees concerning the work environment was "sufficient" and about $50 \%$ of the workers considered that the number of discussions among the parties was "sufficient". The respondents assessed that the work task was generally clearly defined by the employer's goals (Fig. 2B).

More than 50\% of the employees (Fig. 2C) could not influence the issues concerning themselves in the workplace. However, more than one half of the respondents could determine their work pace, they felt that their work was important and they worked independently. 


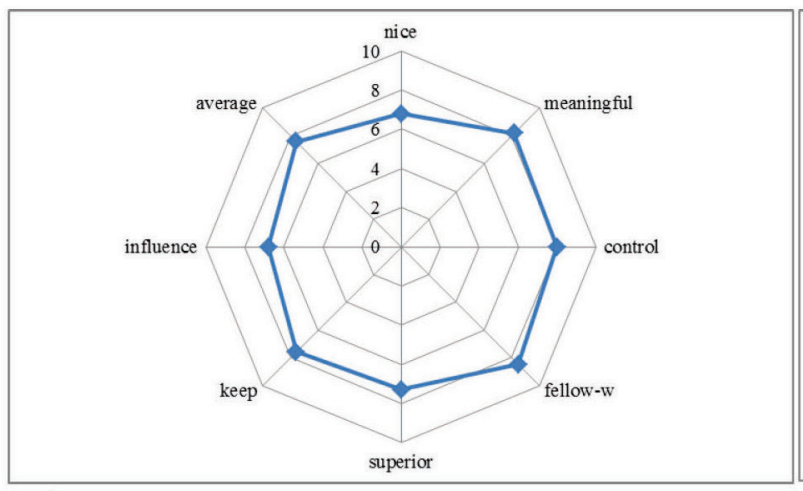

A

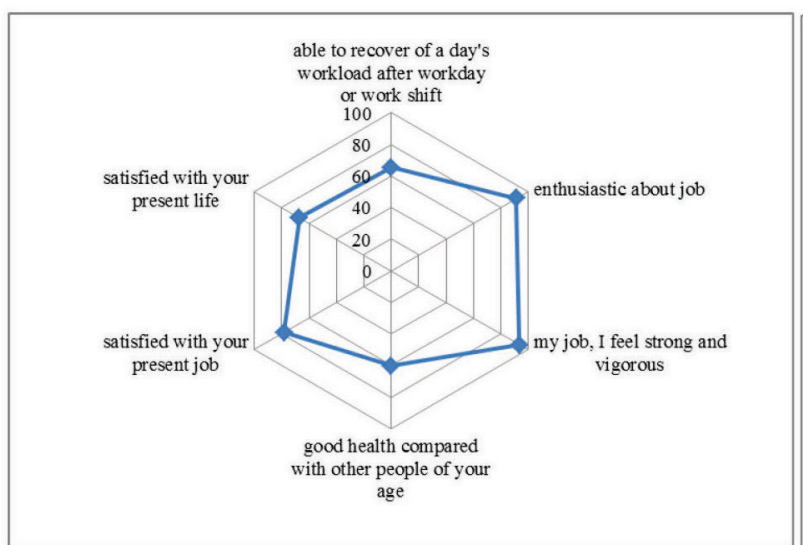

C

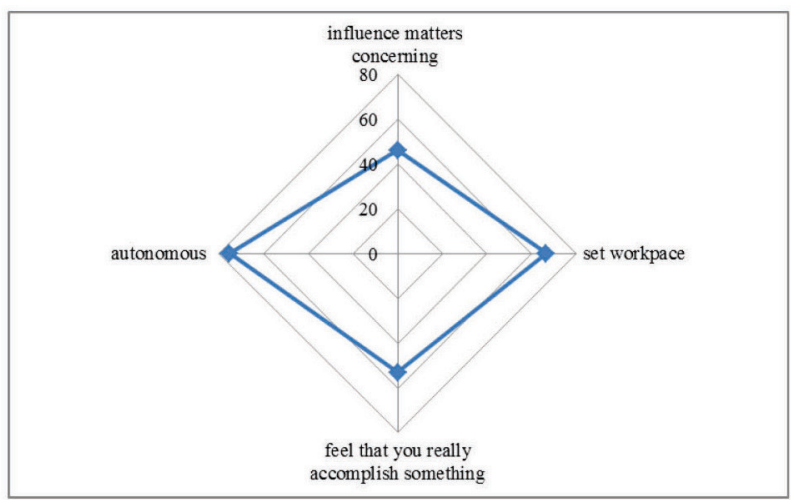

$\mathbf{E}$

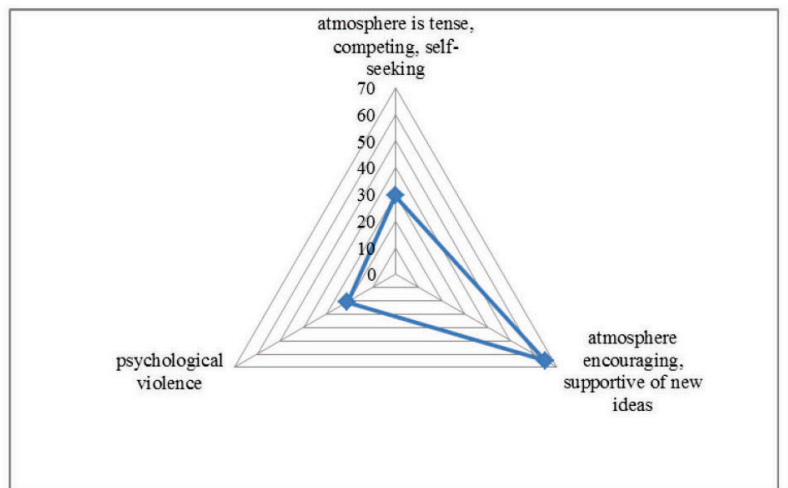

G

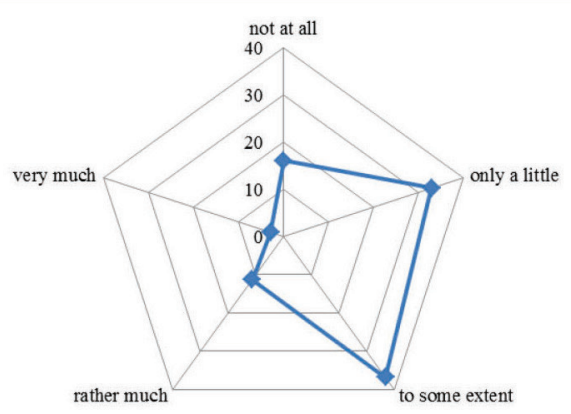

B

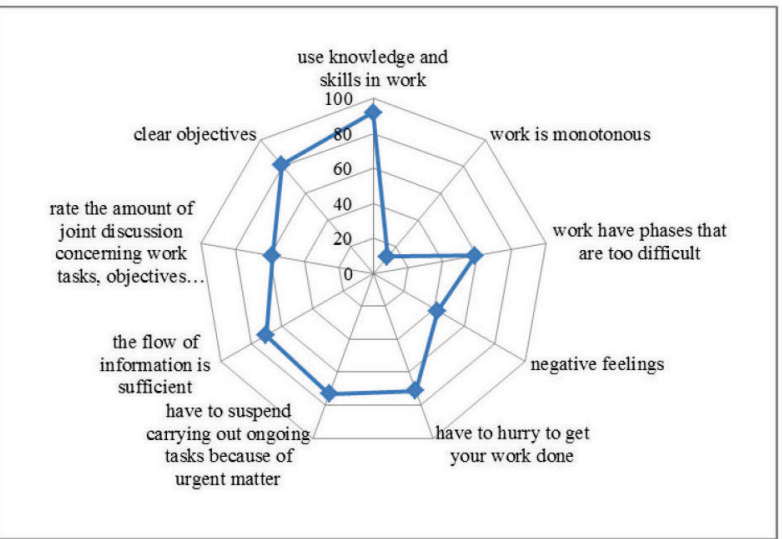

D

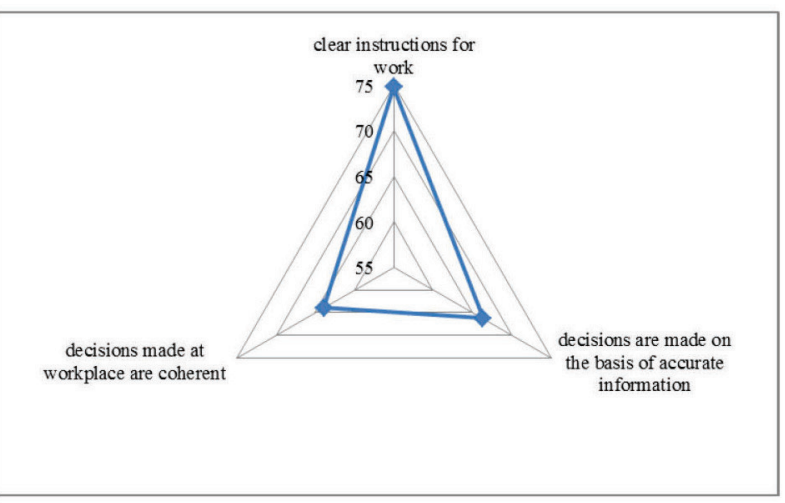

$\mathbf{F}$

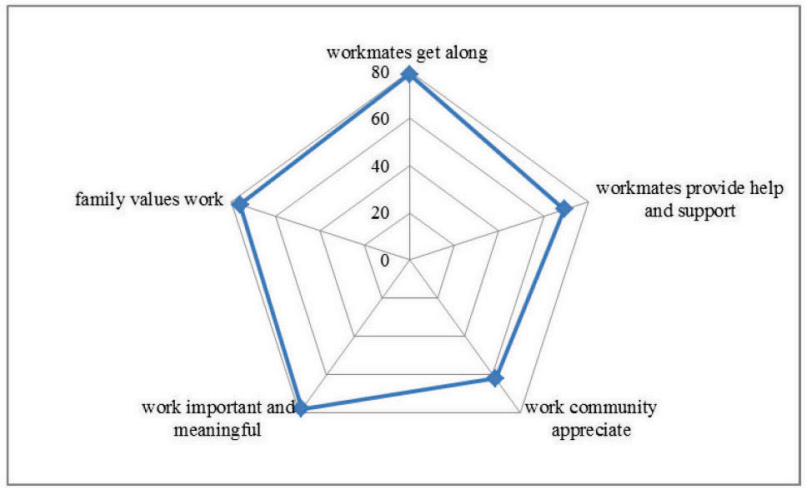

H

Fig. 2. Questionnaire results. A. Results of the Kiva Questionnaire; B. Feeling of stress (WAI + Nordic); C. Well-being of workers (WAI+ Nordic); D. Work demands (WAI+ Nordic); E. Possibility to control the work of a person (WAI+ Nordic); F. Management and supervision (WAI+Nordic); G. Work atmosphere assessed by the workers (WAI+Nordic); H. Psychological violence (Nordic). 
Most of the employees felt that their work was sufficiently guided by the employers, the decisions at the workplace were made according to accurate information and the decisions were coherent. Therefore, the employees were satisfied with their employers and the decisions made by them (Fig. 2D).

Only $1 / 3$ of the respondents assessed the work atmosphere as tense, competitive, and self-centred (Fig. 2E). Most of the workers thought that the work environment was rather encouraging and supportive for new ideas. Psychological violence was felt by one fifth of the employees. Generally, the relationships between fellow workers were good; they offered help and support to each other if necessary, evaluated each other's work, considered their work important and also, families of respondents appreciated their work (Fig. 2F).

Despite the stress sometimes felt by the workers, time pressure, work interruption and intense periods in their work, the respondents were satisfied with their jobs. This was demonstrated both by Kiva and WAI questionnaires. The respondents had sufficient latitude to work, relationships with colleagues were good and the workplace atmosphere also was good. Despite some shortcomings in organisational factors, employees were satisfied with the management. Work stress was felt by $2 / 3$ of the respondents "only a little" or "to some extent". In small doses, stress is good — such as when it helps to conquer fear or provides extra endurance and motivation to get something done (Fig. 2G, 2H).

Based on the data given in Table 1, a disturbing phenomenon was also observed in the assessment of health status of the workers: compared to Group A, Group B of the respondents (working with computers under 10 years) assessed their health status to be at a lower level. The health status assessed as "good": accordingly by $55 \%$ of persons in Group A and $43 \%$ in Group B.

Work in offices is monotonous and the workload might be high. The risk scores for right and left hand are different. The interior architect has to follow the ergonomic principles of workplaces from the beginning of building use. Rehabilitation is necessary for young and ageing workers.

The authors of the present study suggest the following: the complex treatments of office work-related syndromes include active and passive methods of physiotherapy (Ketola et al., 2002; Feuerstein et al., 2004; Gerr et al., 2005). The active part is organised by the physiotherapist. Systematic application of physical education and exercise therapy improves the functional capacity of the organism to physical stress (Mclean et al., 2002). The role of the physical therapist in the occupational health team is to ensure that an optimum work environment exists for the prevention of injury and for the rehabilitation of work-related impairment, activity limitation, and participation restrictions (Brisson et al., 1999; Van den Heuvel, 2003; Sjogren et al., 2005; Brewer et al., 2006). There are also physical therapies that affect tissue metabolic activity and have a positive influence on the repairing process. These are massage, physical agent therapies, and water immersion therapy.

The myometer can be used to determine the basic indicators of the skeletal muscle condition (stiffness and elasticity). This type of data is valuable for the early diagnosis of possible health disturbances caused by work and for planning the rehabilitation treatment in an early stage of overload caused MSDs.

Studies that consider the working conditions, physical overload and psychosocial risk factors are complex and have not been conducted in Estonia until now. Therefore, the results of the project "Workability and Social Inclusion" are very important, as they offer ideas for further research to improve the psychosocial work environment. The results can also be implemented in other post-socialist countries as the work environment is similar for all of these states.

It is possible to reduce physical and psychosocial risk at workplaces by communication, training and solving problems regarding the issues of their complaints. Several hazardous factors (indoor climate, psychosocial factors, static posture etc.) can affect the computer-worker. If improvement in the working environment are implemented, the level of stress of workers can be decreased.

Proposals were given for ergonomic improvements at workplaces (new ergonomic chairs, the possibility to change the height of the worktable; change of the position of a monitor etc.). Complaints about the air of the work environment and lighting deficiency were conveyed to the employer. The rehabilitation of MSDs is possible using balneological methods of treatment and methods of physiotherapy (Tuulik et al., 2013; Visnola et al., 2010; Wargenaar et al., 2012).

MSD questionnaires, objective methods and environmental measurements are useful to plan prevention and early rehabilitation before the disability appears.

\section{ACKNOWLEDGEMENTS}

The work has been supported by the INTERREG IVA Project CB52 WASI "Workability and Social Inclusion' and the Estonian project SF0140022s10 "Chemical Engineering Aspects in Environmental Risk Assessment”.

\section{REFERENCES}

Anonymous (2012). Annual Report of Working Environment. National Labour Inspectorate of Estonia. Available at: http://www.ti.ee/index.php?page=1716\&. Accessed 13 January 2013.

Brauer, C., Mikkelsen, S. (2010). The influence of individual and contextual psychosocial work factors on the perception of the indoor environment at work: A multilevel analysis. Int. Arch. Occup. Environ. Health, 83, 639-651.

Brewer, S., Van Eerd, D., Amick, B. C., Irvin, E., Daum, K. M., Gerr, F., Moore, J. S. Cullen, K., Rempel, D. (2006). Workplace interventions to prevent musculoskeletal and visual symptoms and disorders among computer users: A systematic review. J. Occup. Rehab., 16 (3), 325-358. 
Brisson, C., Montreuil, S., Punnett, L. (1999) Effects of an ergonomic training program on workers with video display units. Scand. J. Work Environ. Health, 25 (3), 255-263.

Eltayeb, S., Staal, J. B., Kennes, J., Lamberts, H. G. P., A. de Bie, R. A. (2007). Prevalence of complaints of arm, neck and shoulder among computer office workers and psychometric evaluation of a risk factor questionnaire. BMC Musculoskeletal Disorders, 8 (68), 1-11.

Feuerstein, M., Nicholas, R. A., Huang, G. D., Dimberg, L., Ali, D., Rogers, H. (2004). Job stress management and ergonomic intervention for workrelated upper extremity symptoms. Appl. Ergon., 35 (6), 565-574.

Galinsky, T., Swanson, N., Sauter, S., Dunkin, R., Hurrell, J., Schleifer, L. (2007). Supplementary breaks and stretching exercises for data entry operators: A follow-up field study. Amer. J. Industr. Med., 50 (7), 519-527.

Gerr, F., Marcus, M., Monteilh, C., Hannan, L., Ortiz, D., Kleinbaum, D. (2005). A randomised controlled trial of postural interventions for prevention of musculoskeletal symptoms among computer users. Occup. Environ. Med., 62 (7), 478-487.

Ketola, R., Toivonen, R., Hakkanen, M., Luukkonen, R., Takala, E. P., Viikari-Juntura, E.; Expert Group in Ergonomics (2002). Effects of ergonomic intervention in work with video display units. Scand. J. Work Environ. Health., 28 (1), 18-24.

Kulin, J., Reaston, M. R. (2011). Musculoskeletal disorders early diagnosis: A retrospective study in the occupational medicine setting. J. Occup. Med. Toxicol., 6, 1-6.

Lindström, K., Elo, A.-L., Skogstad, A., Dallner, M., Gamberale, F., Hottinen, V., Knardahl, S., Orhede, E. (2000). General Nordic Questionnaire for Psychological and Social Factors at Work. Nordic Council of Ministers, Copenhagen.

Malinska, M., Bugajska, J. (2010). The influence of occupational and non-occupational factors on the prevalence of musculoskeletal complaints in users of portable computers. J. Occup. Safety Ergono. (JOSE), 16 (3), $337-343$.

Mclean, L., Tingley, M., Scott, R. N., Rickards, J. (2001). Computer terminal work and the benefit of microbreaks. Appl Ergon., 32 (3), 225-37.

Nag, P. K., Pal, S., Nag, A., Vyas, H. (2009). Influence of arm and wrist support on forearm and back muscle activity in computer keyboard operation. Applied Ergon., 40 (2), 286-291.

Näsman, O. Metal Age and Kiva-questionnaire. Assist in navigation towards well-being at work. Mediona OyAb. The Archipelago Academy for Well-being at Work. Available at:

http://www.mediona.fi/pdf/KANSI\%20Metal\%20Age\%20ja\%20Kiva-ky sely\% Accessed 13 January 2013.

Oha, K., Viljasoo, V., Merisalu, E. (2010). Prevalence of musculoskeletal disorders, assessment of parameters of muscle tone and health status among office workers. Agron. Res., 8 (1), 192-200.
Orsila, R., Luukkaala, T., Manka, M.-L., Nygard, C.-H. (2011). A new approach to measuring work-related well-being. Int. J. Occup. Safety Ergon. (JOSE), 17 (4), 341-359.

Panari, C., Gugliemi, D., Ricci, A., Tabanelli, M. C., Violante, F. S. (2012). Assessing and improving health in the workplace: An integration of subjective and objective measures with the Stress Assessment and Research Toolkit (St.A.R.T.) method. J. Occup. Med. Toxicol., 7, 1-10.

Pillastrini, P., Mugnai, R., Franeti, C., Bertozzi, L., Bonfiglioli, R., Curti, S., Mattioli, S., Violante, F. S. (2007). Evaluation of two preventive interventions for reducing musculoskeletal complaints in operators of video display terminals. Phys Ther., 87 (5), 536-544.

Raja, A., Tuulik, V., Lossmann, E., Meister, A. (1996). Neural network approach to classify the functional state of CNS in case of neurotoxic diseases. Med. Biol. Eng. Comp., 34 (suppl.1), 241-242.

Sjogren, T., Nissen, K. J., Jarvenpaa, S. K., Ojanen, M. T., Vanharanta, H., Malkia, E. A. (2005). Effects of a workplace physical exercise intervention on the intensity of headache and neck and shoulder symptoms and upper extremity muscular strength of office workers: A cluster randomized controlled cross-over trial. Pain, 116 (1-2), 119-128.

Šmite, D., Ancane, G. (2010). Psychosomatic aspects of chronic low back pain syndrome. Proc. Latvian Acad. Sci., Section B, 64 (5/6), 202-208.

Tanabe, S., Nishihara, N. (2004). Productivity and fatigue. Indoor Air, 14 (Suppl 7), 126-133.

Tint, P. Traumann, A., Pille, V., Tuulik-Leisi, V.-R., Tuulik, V. (2011). Computer users' health risks caused by the simultaneous influence of inadequate indoor climate and monotonous work. Agron. Res. Biosyst. Eng., 10 (1), 261-268.

Tuomi, K., Ilmarinen, J., Jahkola, A., Katajarinne, L., Tulkki, A. (1998). Work Ability Index. Helsinki: Finnish Institute of Occupational Health.

Tuulik, V.-R., Tuulik, V., Pille, V., Tamm, M., Saarik, S., Vare, T., Tint, P. (2013). Laser-Doppler perfusion monitoring, myotonometry, and workplace risk evaluation as assessment methods of musculoskeletal overuse syndromes in industry workers. J. Rehab. Med., 45, 976-977.

Van den Heuvel, S. G., De Looze, M. P., Hildebrandt, V. H., The, K. H. (2003). Effects of software programs stimulating regular breaks and exercises on work-related neck and upper-limb disorders. Scand. J. Work Environ. Health, 29 (2), 106-116

Vain, A., Kums, T. (2002). Criteria for preventing overtraining of the musculoskeletal system of gymnasts. Biol. Sport, 19 (4), 329-345.

Visnola, D., Sprudza, D., Bake, M. A., Pike, A. (2010). Effects of art therapy on stress and anxiety of employees. Proc. Latvian Acad. Sci., Section B, 64 $(1 / 2), 85-91$.

Wagenaar, A. F., Kompier, M. A. J., Houtman, I. L., D., van den Bossche, S., N., J. Taris, T.W. (2012). Employment contracts and health selection. Unhealthy employees out and healthy employees in? J. Occup. Environ. Manag., 54 (10), 1192-1200.

Zakerian, S. A., Subramaniam, I. D. (2009). The relationship between psychological work factors, work stress and computer-related musculoskeletal discomforts among computer users in Malasia. Int. J. Occup. Safety Ergonomics (JOSE), 15 (4), 425-434.

Received 20 July 2014

\section{FIZISKU UN FIZIOLOGISKU RISKU IZRAISITTU VESELĪBAS TRAUCĒJUMU PROFILAKSE DARBINIEKIEM, KAS STRĀDĀ AR DATORU}

Pētījums veikts projekta Interreg 4A "Efektivitāte un sociālā iekḷaušanās" ietvaros. Apkopoti dati, kas iegūti, apstrādājot 192 darbiniekus, kuru darba vietas aprīkotas ar datoru, anketas (Nordic, darbspēju indeksa un Kiva anketas). Pētījuma rezultāti parādīja, ka darbinieki novērtē savu veselības stāvokli kā labu. Turpinot monotono darbu pie datoriem, darbinieki uzskata, ka viṇu veselības stāvoklis nākotnē nepasliktināsies, ja tiks veikta regulāra rehabilitācija. Visjutīgākie pret nogurumu ir rokas un kakla muskuḷi. Nepieciešams izstrādāt rehabilitācijas programmu, un tai ir jābūt pieejamai pēc iespējas vairāk darba ṇēmējiem. Pētījumā darbinieki tika sadalīti divās grupās: A grupa, darba stāžs ar datoru līdz 10 gadiem (ieskaitot) un B grupa, darbs ar datoru vairāk nekā 10 gadi. Tika konstatêts, ka psihosociālo riska faktoru novērtēšanas rezultāti abām grupām atškīinās — psihosociālo darba apstākḷu novērtējums B grupai bija labāks nekā A grupai. B grupas darbinieki vairāk baidījās zaudēt darbu, un viṇiem nebija augstas prasības darba videi. 